\title{
Modelling the occurrence of postflexion stages of a marine estuarine-dependent fish in temperate South African estuaries
}

\author{
Yanasivan Kisten ${ }^{1,2}$, Nadine A. Strydom ${ }^{2}$, Renzo Perissinotto ${ }^{1}$, Sourav Paul ${ }^{1}$ \\ ${ }^{1}$ DST/NRF Research Chair in Shallow Water Ecosystems, Nelson Mandela Metropolitan University, \\ Summerstrand Campus South, P.O. Box 77000, Port Elizabeth 6031, South Africa. \\ (YK) (Corresponding author) E-mail: yanasivan@gmail.com. ORCID iD: http://orcid.org/0000-0001-5468-0230 \\ (RP) E-mail: renzo.perissinotto@nmmu.ac.za. ORCID iD: http://orcid.org/0000-0002-9224-3573 \\ (SP) E-mail: souravpaul4@ gmail.com. ORCID iD: http://orcid.org/0000-0003-4657-9655 \\ ${ }^{2}$ Department of Zoology, Nelson Mandela Metropolitan University, Summerstrand Campus South, P.O. Box 77000, \\ Port Elizabeth 6031, South Africa. \\ (NAS) E-mail: nadine.strydom@nmmu.ac.za. ORCID iD: http://orcid.org/0000-0003-4292-8678
}

\begin{abstract}
Summary: The movement of postflexion larvae of marine estuarine-dependent species into estuaries is critical for the survival of fishes reliant on estuaries as nurseries. However, detailed studies focused on environmental variability experienced by postflexion larvae entering a range of estuary types under varying conditions are rare. This study assessed the in situ conditions (temperature, salinity and water clarity) under which the southern African endemic fish Rhabdosargus holubi (Sparidae) recruits into estuaries. Postflexion larvae were sampled in three biogeographic regions (cool temperate, warm temperate and subtropical boundary), which included three estuary types (permanently open estuaries (POEs), temporarily open/closed estuaries and estuarine lake systems) on a seasonal basis, independent of each other. Rhabdosargus holubi larvae were more abundant in spring and summer, in POEs in the warm temperate region. Models predicted that higher larval occurrence in estuaries is a function of lower salinity (e.g. mesohaline zones of 5-17.9 salinity) and lower water clarity (e.g. 0-0.2 $\mathrm{K}_{\mathrm{d}}$, light extinction coefficient), particularly for warm, temperate POEs. This re-emphasizes the importance of freshwater for optimal nursery functioning, which may be compromised by impoundments, abstraction and climate change in water-short countries like South Africa.
\end{abstract}

Keywords: biogeography; fish larvae; recruitment; Rhabdosargus holubi; salinity; turbidity.

Modelización de la aparición de larvas en estadio de postflexión de un pez estuárico dependiente en los estuarios templados de Sudáfrica

Resumen: En las especies de peces dependientes de los estuarios marinos como zonas de cría, el movimiento de las larvas en estadio de postflexión hacia el interior de los estuarios es un proceso crítico para su supervivencia. Sin embargo, son raros los estudios detallados que analicen la variabilidad ambiental experimentada por estas larvas en diversos ambientes estuáricos. Este estudio evaluó las condiciones in situ (temperatura, salinidad y claridad del agua) bajo las que Rhabdosargus holubi (Sparidae), pez endémico de África meridional, recluta en los estuarios. Las larvas en postflexión se muestrearon estacionalmente en tres regiones biogeográficas, independientes entre sí, (templada-fría, templada-cálida y subtropical), que incluían tres tipos de estuarios (POE: estuarios permanentemente abiertos, TOC: estuarios temporalmente abiertos/cerrados y ELS: sistemas de lagos estuarinos). Las larvas de Rhabdosargus holubi fueron más abundantes durante la primavera y el verano, en POEs de la región templada-cálida. Los modelos predijeron que la mayor aparición de larvas en los estuarios es función de una menor salinidad (por ejemplo, zonas mesohalinas de 5-17.9 salinidad) y una menor claridad del agua (por ejemplo con coeficiente de extinción de luz de $0-0.2 \mathrm{~K}_{\mathrm{d}}$, particularmente para POEs templado-cálidos. Esto reafirma la importancia del agua dulce para el funcionamiento óptimo como zona de cría, que puede verse comprometida por los embalses, la extracción de agua y el cambio climático en países con escasez de agua como Sudáfrica.

Palabras clave: biogeografía; larvas de peces; reclutamiento; Rhabdosargus holubi; salinidad; turbidez.

Citation/Como citar este artículo: Kisten Y., Strydom N.A., Perissinotto R., Paul S. 2017. Modelling the occurrence of postflexion stages of a marine estuarine-dependent fish in temperate South African estuaries. Sci. Mar. 81(1): 27-35. doi: http://dx.doi.org/10.3989/scimar.04521.05A

Editor: M.P. Olivar.

Received: July 21, 2016. Accepted: November 18, 2016. Published: January 23, 2017.

Copyright: () 2017 CSIC. This is an open-access article distributed under the terms of the Creative Commons Attribution (CC-by) Spain 3.0 License. 


\section{INTRODUCTION}

Many marine estuarine-opportunist and -dependent fish species in the Southern Hemisphere enter estuaries at the postflexion larval stage for protection, shelter, food, optimal growth and development (Neira et al. 1992, Whitfield 1994, Strydom 2015). However, compared with their counterparts in the marine environment, the larvae experience dynamically changing salinity, water temperature and turbidity, which influence their recruitment, survival, growth and distribution (Boehlert and Mundy 1988, Whitfield 1994). In estuaries, temperature is often higher than in the marine environment and this favours growth in early-stage fishes (Boehlert and Mundy 1988, Fielder et al. 2005, Strydom et al. 2014). Likewise, fluctuations in salinity influence energetic demands of fish larvae under specific estuarine conditions, impacting on survival, behaviour and distribution (Fielder et al. 2005, Bodinier et al. 2010). Some fish larvae use low-salinity and high-turbidity zones of estuaries to avoid predators, thus increasing their chances of survival (Boehlert and Mundy 1988, Lehtiniemi et al. 2005). Often, low-salinity and highturbidity zones are nutrient-rich, leading to increases in productivity and thus food availability for larval fishes (Whitfield 1994, Islam et al. 2006, Strydom 2015). Cueing, recruitment and movement studies have also shown the importance of high freshwater flow and related olfactory cues, temperature, turbidity and low salinity in the movement of larval and juvenile fish into and within estuaries (Boehlert and Mundy 1988, Strydom 2003, Kisten et al. 2015). Similarly, environmental variables also affect the distribution of fish species among estuaries, as driving factors such as seasonal spawning and recruitment times, regional climate (e.g. temperate vs. tropical), inter-annual climate variability such as El Niño-Southern Oscillation (ENSO) and estuarine typology (e.g. estuaries that are permanently open, temporarily open or exhibiting lake basins, i.e. permanently open estuaries (POEs) vs. temporarily open/closed estuaries (TOCs) vs. estuarine lake systems (ELS) determine the structure of fish populations and communities (Harrison and Whitfield 2006, Koehn et al. 2011, Strydom 2015).

Of the five types of estuaries currently recognized in South Africa, POE and TOC systems dominate the coastline, providing a critical nursery habitat for the marine estuarine-opportunist and estuarine-dependent species (Whitfield 1998, Strydom and Whitfield 2000, Strydom 2015). The South African shoreline consists of various climatic biogeographical regions, from cool temperate on the south western coast to subtropical in the northeast, providing a variety of environments for fish to inhabit (Whitfield 1998). Much is known about fish larvae and juvenile assemblages within and among temperate South African estuaries (Strydom et al. 2003, Vorwerk et al. 2003, Strydom 2015), but work is limited on large spatial scales focusing on a single species response to the range of environmental variability characterizing estuaries along the South African coast. This is important because the survival and distribution of many marine estuarine-opportunist and estuarine- dependent species such as Rhabdosargus holubi, which in its juvenile stage exert a significant ecological effect as a herbivore and prey species for piscivorous fish and birds, emphasize the success of estuaries as nurseries and feeding areas (Blaber 1973, Whitfield 1998). However, South African estuaries are subject to irregular freshwater input and warming coastal waters which may place them at risk (Gillanders et al. 2011, IPCC 2013, 2014).

The Cape stumpnose, Rhabdosargus holubi, is a common endemic species along the southern African coast, extending from the Great Berg Estuary on the cool temperate southwest coast to Inhaca Island in the subtropical northeast (Blaber 1973, Whitfield 1998). Rhabdosargus holubi is a shallow water, marine species that is dependent on estuaries for its early life history until sexual maturity at $\pm 150 \mathrm{~mm}$ standard length (Blaber 1973, Whitfield 1998). Adults typically spawn in the ocean from late winter to summer and postflexion larvae recruit from the surf zone into estuarine nurseries, where they undergo metamorphosis into juveniles (Beckley 1984, Whitfield 1994, Strydom 2003). The environmental dynamics of estuaries, coupled with varying estuary types and climatic regions along the temperate coast of South Africa, create a wide range of conditions that recruiting postflexion $R$. holubi larvae are subjected to (Strydom 2015). This, together with the ubiquity of this estuarine specialist species, makes $R$. holubi a good candidate for modelling the occurrence dynamics of a postflexion stage marine estuarine-dependent fish into estuaries over a large spatial scale. The present study aims to assess the relative importance of temperature, turbidity and salinity in determining the occurrence and abundance of the larval stages of this marine estuarinedependent fish in estuaries. Consequently, the abundance of postflexion larvae of $R$. holubi in 25 estuaries along the temperate South African coast was assessed in order to understand the environmental conditions (temperature, salinity and water clarity) characterizing the recruitment phase of this species into estuaries and to provide a benchmark for comparison and prediction of potential future changes. For this purpose, multiple working a priori hypotheses were set before the analyses. These included that the occurrence and abundance of $R$. holubi postflexion larvae differs between: 1) biogeographic regions, due to the difference in climate and associated environmental variables; 2) estuarine types, due to the difference is access opportunities; and 3) seasons, due to the changes in temperature and freshwater input. Consequently, it was further hypothesized that the density of $R$. holubi postflexion larvae present in estuaries is determined by a combination of temperature, salinity and water clarity.

\section{MATERIALS AND METHODS}

\section{Study areas}

The environmental and larval abundance data for this study were excised from a larger study investigating larval fish communities in 25 temperate estuaries in South Africa (Fig. 1), further details of which can 


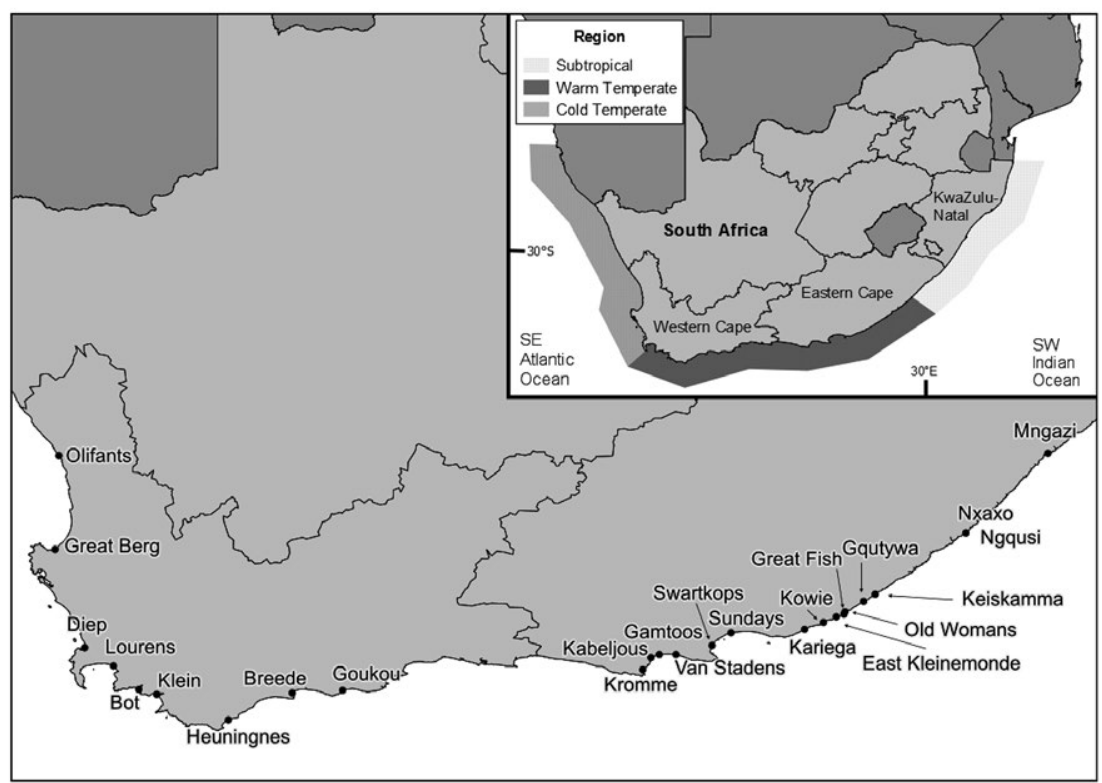

Fig. 1. - Location of estuaries sampled for fish larvae along the South African coast by Strydom (2015).

be found in Strydom (2015) and references therein. Sampling took place between 1998 and 2009 and included three types of estuaries (POE, TOC and ELS) in three different biogeographic regions (cool temperate, warm temperate and warm temperate/subtropical boundary, according to Harrison and Whitfield (2006). Each estuary was sampled over four seasons (spring, summer, autumn, winter) and measurements were taken for a wide range of environmental variables, including salinity, temperature and water clarity (Table 1 and 2). Only summer/winter data were available for Mngazi, Ngqusi and Nxaxo. Each estuary was sampled at least once during the 10-year period; sampling dates are detailed in Table 1. The region (Fig. 1) included a cool temperate climate with high rainfall in winter in the west, to warm temperate bordering on subtropical climate in the east, with bimodal rainfall in autumn and spring (Strydom 2015). Estuaries sampled in 1998-1999 and 2008-2009 occurred during the La Niña phase of ENSO (0.3-1.8 SOI), whereas the remaining estuaries varied in El Niño and La Niña phases $(-1.8-0.4)$ between seasons within each year (www.cgd.ucar.edu/cas/catalog/climind/soi.html).

\section{Field sampling}

Postflexion stages of $R$. holubi were collected between 1998 and 2009 using a standardized sampling protocol described in Strydom (2015) for each estuary sampled (Table 1). Each estuary was sampled for one year within this time period. Plankton tows were conducted via boat at near-equidistant stations along the length of each estuary. A 4.5-m boat was used to sample POEs, while a $2.5-\mathrm{m}$ boat was used for smaller TOCs and ELS. Two slightly modified WP-2 plankton nets of $570 \mathrm{~mm}$ mouth diameter and $0.2 \mathrm{~mm}$ mesh aperture fitted with Kahlsico 005 WA 130 flowmeters were used to sample fish larvae at each station. Nets were deployed from a 3-m boom attached to the bow of the boat. In each estuary (Table 1), two samples were collected per station in each season over one year during the 10-year period. Towing was conducted at each station in darkness (after sunset) for three minutes, resulting in approximately $12-16 \mathrm{~m}^{3}$ of water filtered for each sample. Nets were towed in the upper $0.8 \mathrm{~m}$ of the water column at a speed of 1-2 knots. Samples were fixed in $10 \%$ buffered formalin in estuarine water and returned to the laboratory for density counts. Fish were identified and measured to the nearest $0.1 \mathrm{~mm}$ for body length using a micrometer or Vernier callipers. Larval fish density was expressed as number of larvae per $100 \mathrm{~m}^{3}$ of water filtered, after volume calibrations. Temperature $\left({ }^{\circ} \mathrm{C}\right)$ and salinity were measured at each station using either a Valeport CTD instrument or a YSI 6600 Multi-parameter meter. Secchi depth (D in $\mathrm{cm}$ ) was used as a proxy for water transparency at each station. Water transparency was calculated as extinction coefficient $(\mathrm{k})$, where $\mathrm{k}=1.7 / \mathrm{D}$ (Dawes 1998). Stations were categorized into salinity zones based on a slightly modified Venice system appropriate for South African estuaries (Strydom et al. 2003). This included the following salinity zones and salinity ranges: Fresh (F) $=0-0.49$; Oligohaline $(\mathrm{O})=0.5-4.9$; Mesohaline $(\mathrm{M})$ =5.0-17.9; Polyhaline $(\mathrm{P})=18.0-29.9 ;$ Euhaline $(\mathrm{E})$ $=30.0-35.9 ;$ Hypersaline $(\mathrm{H}) \geq 36$.

\section{Statistics}

Results of Shapiro-Wilk tests showed that data of salinity $(\mathrm{W}=0.08, \mathrm{p}<0.005)$, water clarity $(\mathrm{W}=0.2$, $\mathrm{p}<0.005)$, temperature $(\mathrm{W}=0.98, \mathrm{p}<0.005)$ and $R$. holubi larval density $(\mathrm{W}=0.15, \mathrm{p}<0.005)$ were not normally distributed. Therefore, Kruskal-Wallis ANOVAs or Mann-Whitney-Wilcoxon tests (depending on where $R$. holubi were found) were used to compare the above variables between biogeographical regions (i.e. cool temperate, warm temperate and warm temperate/subtropical boundary), estuary types 


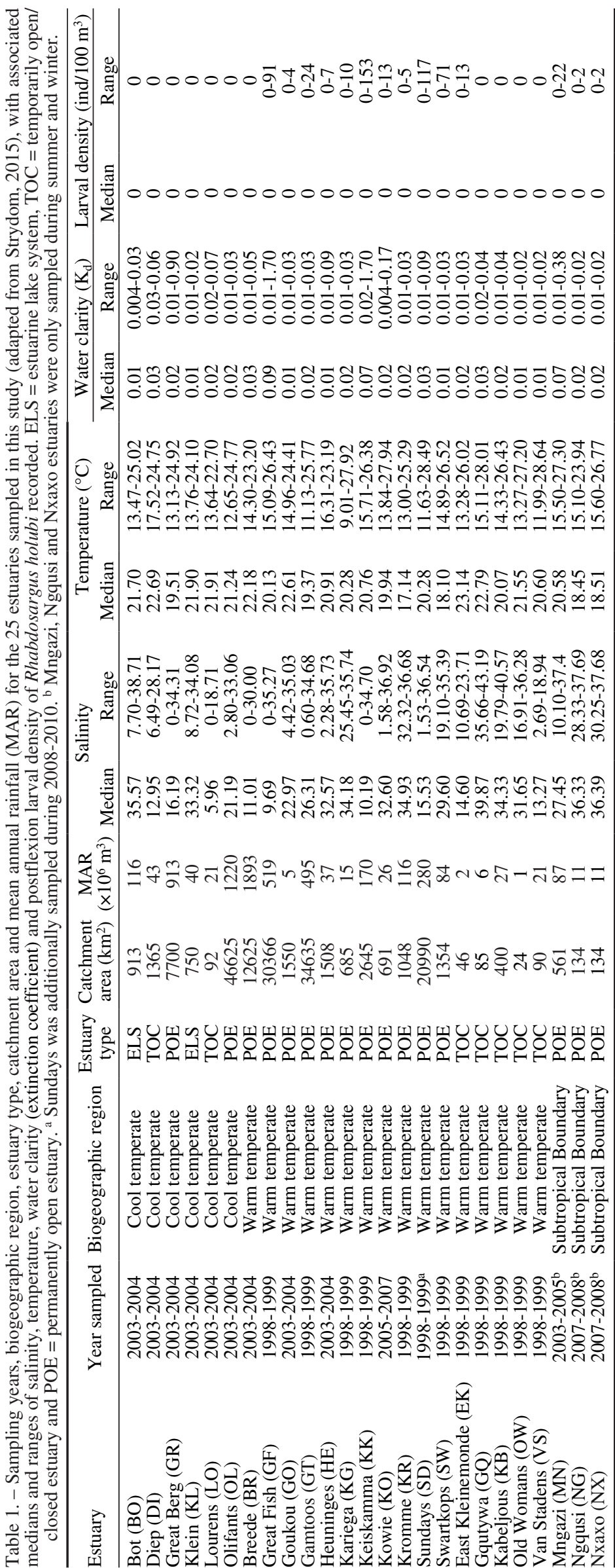

(i.e. POEs, TOCs and ELS) and seasons (i.e. spring, summer, autumn and winter). These were followed by 'Nemenyi' post-hoc tests where necessary, using the 'PMCMR' package in CRAN R 3.2.1 for Windows (R Core Team 2015). All the confidence intervals were set at $95 \%$. K-W $\left(\chi^{2}\right)$ and $p$ values with associated DF were reported.

\section{Analysis of larval density data}

No Rhabdosargus holubi individuals were found in the cool temperate region or in ELS systems, while only one TOC system exhibited fish in the sample collections, so these were not included in further data analyses. Thus, analyses of variability of $R$. holubi larval density were focused on POEs in the warm temperate and boundary zones. To determine whether $R$. holubi density (ind $\mathrm{m}^{-3}$ ) varied with 'Season', 'Salinity', 'Temperature' and 'Water clarity', generalized linear mixed models (GLMMs) were built in CRAN R 3.2.1 for Windows (R Core Team 2015). The aim was to determine the probable a priori hypotheses by using $\mathrm{Ai}$ kake's Information Criterion (AIC), i.e. the model with the lowest AIC value. Fish larval density followed an over-dispersed Poisson distribution, so the glmmADMB function of the 'glmmADMB' package was used with the negative binomial ('nbinom1') family. The dataset also exhibited $>40 \%$ zero values, due to either inadequate sampling or absence of $R$. holubi at certain sites, biogeographic regions or estuaries during parts of the year. Thus, the models were extended to zero-inflation for a better fit. The dataset had a hierarchical structure because the sites were sampled within each estuary falling under different regions. Therefore, a random variable (i.e. 1|site) was added to the intercepts of all the models to capture the variance which may be specific to a particular site. Models were restricted to second-order interactions for easier ecological interpretability. AIC values were corrected to compensate for a small dataset with over-dispersion, by using the following formula:

$$
\text { QAICc }=-\frac{2 \log (\text { likelihood })}{\omega}+2 \theta+\frac{2 \theta(\theta+1)}{n-\theta-1}
$$

where $\omega$ is the dispersion parameter, $\theta$ is the number of parameters in the model, and $\mathrm{n}$ is the sample size. Models were ranked based on $\triangle$ QAICc values (i.e. difference of QAICc value of a model from the model with the lowest QAICc value). It was assumed that models with $\Delta$ QAICc $<0.5$ were equally probable, while models with $\triangle$ QAIC $\leq 4$ were considered to have partial data support. Models with $\triangle$ QAIC $>4$ had minimal data support and were therefore not discussed further (Burnham and Anderson 2002). 

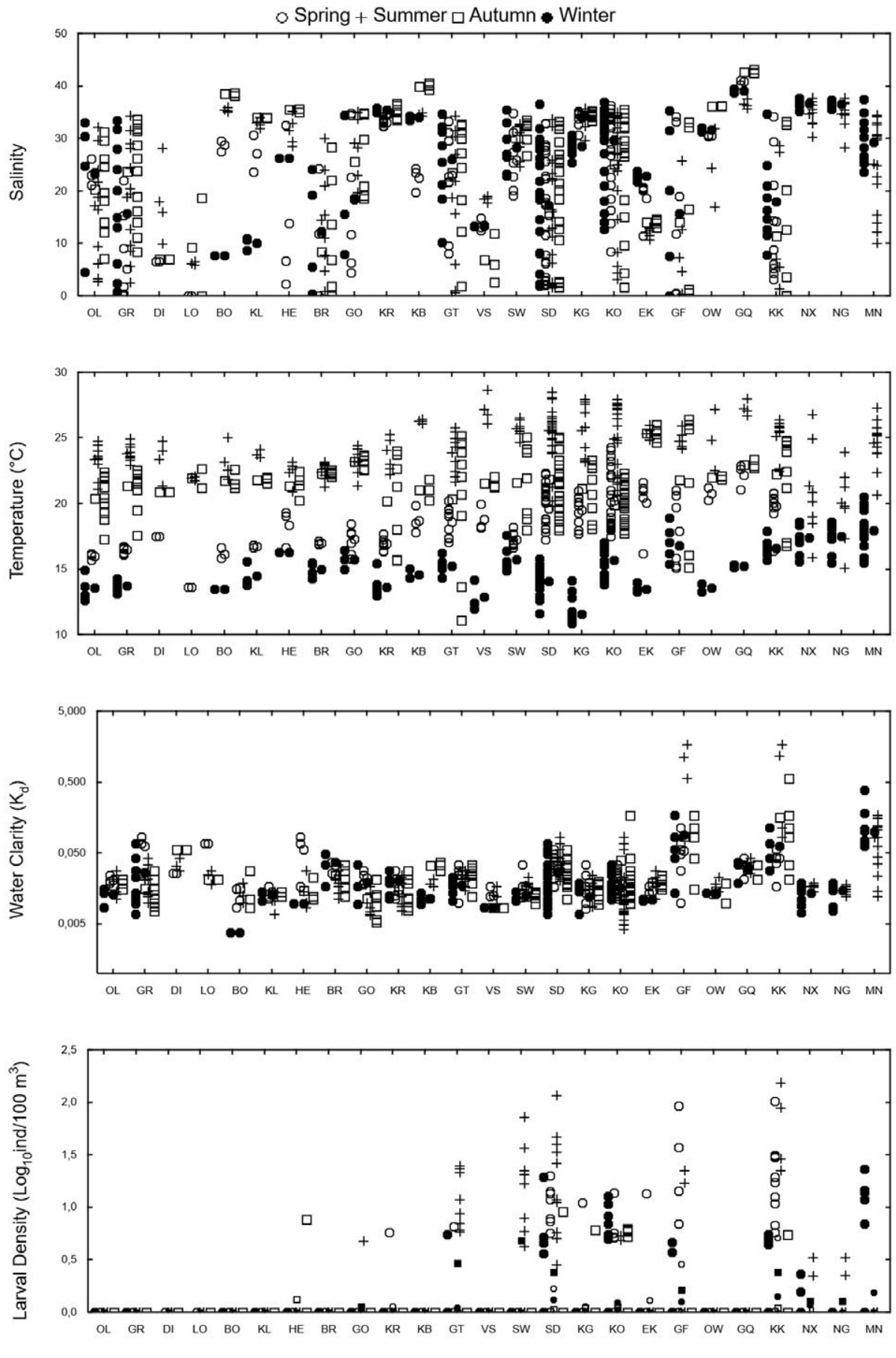

Fig. 2. - Seasonal salinity, temperature, water clarity and postflexion larval density of Rhabdosargus holubi in 25 estuaries on the South African coast. Estuary names and codes are specified in Table 1.

\section{RESULTS}

\section{Variability in environmental parameters}

Median and range of salinity, temperature, water clarity and larval density for each estuary are shown in Table 1 and Figure 2, with seasonal, regional and typological values shown in Table 2. Salinity levels varied between seasons $\left(\chi^{2}=8.64, \mathrm{df}=3, \mathrm{p}=0.03\right)$, with spring showing lower values than winter $(\mathrm{p}<0.005$, Table 2). Biogeographical regions $\left(\chi^{2}=55.16, \mathrm{df}=2\right.$, $\mathrm{p}<0.005)$ exhibited considerable variations in salinity, in particular estuaries in the boundary (subtropical/ warm temperate) region were more saline than those of the warm temperate region $(p<0.005$, Table 2$)$. Finally, individual estuaries exhibited considerable differences in salinity levels $\left(\chi^{2}=598.25, \mathrm{df}=24, \mathrm{p}<0.005\right)$.

Water clarity also differed between seasons $\left(\chi^{2}=16.74, \mathrm{df}=3, \mathrm{p}<0.005\right)$ and biogeographic regions $\left(\chi^{2}=23.89, \mathrm{df}=2, \mathrm{p}<0.005\right)$, and within individual estuaries $\left(\chi^{2}=516.48, \mathrm{df}=24, \mathrm{p}<0.005\right)$. Higher clarity was recorded in boundary region estuaries $(p<0.005$, Table 
Table 2. - Seasonal, regional and typological medians and ranges of salinity, temperature, water clarity and postflexion larval density of Rhabdosargus holubi recorded in 25 estuaries in temperate South Africa. Estuarine Type: ELS, estuarine lake system; TOC, temporarily open/ closed estuary; and POE, permanently open estuary. Regions: Cool, Cool Temperate Region; Warm, Warm Temperate Region; Boundary, Warm temperate/Subtropical Boundary. Superscript letters (, b, c) indicate statistical similarity between treatments according to KruskalWallis ANOVAs.

\begin{tabular}{|c|c|c|c|c|c|c|c|c|c|}
\hline \multirow{2}{*}{ Factor } & & \multicolumn{2}{|c|}{ Salinity } & \multicolumn{2}{|c|}{ Temperature $\left({ }^{\circ} \mathrm{C}\right)$} & \multicolumn{2}{|c|}{ Water clarity $\left(\mathrm{K}_{\mathrm{d}}\right)$} & \multicolumn{2}{|c|}{ Larval density (ind $/ 100 \mathrm{~m}^{3}$ ) } \\
\hline & & Median & Range & Median & Range & Median & Range & Median & Range \\
\hline \multirow{5}{*}{ Season } & Spring & $24.18^{\mathrm{a}}$ & $0-41.15$ & $18.41^{\mathrm{a}}$ & $13.64-24.25$ & $0.02^{\mathrm{a}}$ & $0.01-0.11$ & $0^{\mathrm{a}}$ & $0-102$ \\
\hline & Summer & $27.21^{\mathrm{ab}}$ & $0-7.69$ & $24.53^{\mathrm{b}}$ & $15.10-28.64$ & $0.02^{b}$ & $0-1.7$ & $0^{\mathrm{a}}$ & $0-153$ \\
\hline & Autumn & $28.60^{\mathrm{ab}}$ & $0-43.19$ & $21.71^{\mathrm{c}}$ & $0-26.43$ & $0.02^{\mathrm{b}}$ & $0-0.57$ & $0^{\mathrm{b}}$ & $0-8$ \\
\hline & Winter & $27.97^{\mathrm{b}}$ & $0-39.52$ & $15.27^{\mathrm{d}}$ & $0-20.5$ & $0.02^{b}$ & $0.004-38$ & $0^{\mathrm{b}}$ & $0-22$ \\
\hline & ELS & $34.03^{\mathrm{a}}$ & $7.77-38.71$ & $21.88^{\mathrm{a}}$ & $13.47-25.02$ & $0.01^{\mathrm{a}}$ & $0.004-0.03$ & $0^{\mathrm{a}}$ & $0-0$ \\
\hline \multirow[t]{3}{*}{ Type } & TOC & $21.26^{\mathrm{b}}$ & $0-43.19$ & $21.36^{\mathrm{a}}$ & $11.99-28.64$ & $0.02^{\mathrm{a}}$ & $0.001-0.7$ & $0^{\mathrm{b}}$ & $0-13$ \\
\hline & POE & $27.33^{\mathrm{c}}$ & $0-37.69$ & $20.15^{\mathrm{a}}$ & $0-28.49$ & $0.02^{b}$ & $0-1.7$ & $0^{c}$ & $0-153$ \\
\hline & Cool & $20.27^{\mathrm{a}}$ & $0-2.65$ & $21.59^{\mathrm{a}}$ & $12.65-25.02$ & $0.02^{\mathrm{a}}$ & $0.004-0.09$ & $0^{\mathrm{a}}$ & $0-0$ \\
\hline \multirow{2}{*}{ Region } & Warm & $27.80^{\mathrm{b}}$ & $0-43.19$ & $20.37^{\mathrm{a}}$ & $0-28.64$ & $0.02^{\mathrm{a}}$ & 0-1.7 & $0^{\mathrm{b}}$ & $0-153$ \\
\hline & Boundary & $32.20^{c}$ & $10.10-37.69$ & $19.67^{a}$ & $15.10-27.30$ & $0.06^{\mathrm{b}}$ & $0-0.38$ & $0^{\mathrm{b}}$ & $0-22$ \\
\hline
\end{tabular}

Table 3. - GLMM model AIC values of Rhabdosargus holubi postflexion larval densities modelling the effect of season, salinity, temperature and water clarity for permanently open estuaries in warm temperate and warm temperate/subtropical boundary regions. AIC values were corrected for quasi Poisson distributions and sample size (QAICc). Sample sizes are given as ' $n$ ' and negative binomial dispersion is given as ' $\omega$ '.

\begin{tabular}{|c|c|c|c|c|c|c|c|c|}
\hline Region & Model & Predictors & $\mathrm{n}$ & Log-Likelihood & $\omega$ & Zero-Inflation & QAICc & $\Delta \mathrm{AIC}$ \\
\hline Warm & 1 & Salinity $\times$ Clarity & 832 & -599.98 & 26.08 & 0.76 & 50.02 & 0.00 \\
\hline \multirow[t]{6}{*}{ Temperate } & 2 & Salinity & 832 & -617.39 & 25.09 & 0.82 & 51.22 & 1.20 \\
\hline & 3 & Clarity & 832 & -623.01 & 21.56 & 0.88 & 59.80 & 9.78 \\
\hline & 4 & Clarity $\times$ Temperature & 832 & -611.33 & 20.88 & 0.84 & 62.57 & 12.55 \\
\hline & 5 & Temperature & 832 & -617.78 & 19.22 & 0.87 & 66.30 & 16.27 \\
\hline & 6 & Season & 832 & -606.66 & 18.24 & 0.84 & 68.54 & 18.51 \\
\hline & 7 & Salinity $\times$ Temperature & 832 & -608.37 & 18.65 & 0.82 & 69.24 & 19.22 \\
\hline \multirow[t]{7}{*}{ Boundary } & 1 & Salinity & 92 & -57.97 & 18.74 & $<0.005$ & 8.23 & 0.00 \\
\hline & 2 & Clarity & 92 & -63.25 & 20.05 & $<0.005$ & 8.35 & 0.12 \\
\hline & 3 & Temperature & 92 & -60.72 & 16.03 & 0.50 & 9.62 & 1.39 \\
\hline & 4 & Salinity $\times$ Temperature & 92 & -57.66 & 18.43 & $<0.005$ & 10.39 & 2.16 \\
\hline & 5 & Salinity $\times$ Clarity & 92 & -54.23 & 3.01 & 0.46 & 15.82 & 7.59 \\
\hline & 6 & Season & 92 & -61.55 & 5.99 & 0.82 & 22.59 & 14.36 \\
\hline & 7 & Clarity $\times$ Temperature & 92 & -51.11 & 1.00 & 0.82 & 106.26 & 98.02 \\
\hline
\end{tabular}

Table 4. - Best GLMM model statistics (using $\triangle \mathrm{AIC}$, Table 3) describing the influence of environmental variables on Rhabdosargus holubi postflexion larval densities in permanently open estuaries in warm temperate or warm temperate/subtropical boundary regions. Sal, Salinity; Clar, Clarity; Temp, Temperature.

\begin{tabular}{|c|c|c|c|c|c|c|c|}
\hline Region & Model (Table 4) & $\triangle \mathrm{AIC}$ & Factors & Slope & Slope SE & $\mathrm{Z}$ & $\mathrm{p}$ \\
\hline Warm & 1) Density $\sim$ Sal $\times$ Clar & 0.00 & Sal & -0.13 & 0.02 & -6.86 & $<0.005$ \\
\hline Temperate & & & Clar & -24.64 & 4.88 & -5.05 & $<0.005$ \\
\hline \multirow{5}{*}{ Boundary } & & & Sal × Clar & 2.08 & 0.39 & 5.38 & $<0.005$ \\
\hline & 2) Density $\sim$ Sal & 1.20 & Sal & -0.07 & 0.02 & -4.17 & $<0.005$ \\
\hline & 1) Density Sal & 0.00 & Sal & 0.25 & 0.11 & 2.38 & 0.02 \\
\hline & 2) Density Clar & 0.12 & Clar & -2.68 & 5.26 & -0.51 & 0.61 \\
\hline & 3) Density $\sim$ Temp & 1.39 & Temp & -0.24 & 0.13 & -1.92 & 0.06 \\
\hline
\end{tabular}

2). Clarity was lower during in spring than in any other season $(\mathrm{p}<0.005$, Table 2$)$.

However, temperature did not differ between biogeographic regions $\left(\chi^{2}=0.76, \mathrm{df}=2, \mathrm{p}=0.68\right)$ or individual estuaries $\left(\chi^{2}=34.64, \mathrm{df}=24, \mathrm{p}=0.07\right)$. Temperature varied between seasons $\left(\chi^{2}=882.95, \mathrm{df}=3, \mathrm{p}<0.005\right)$, with higher values recorded in summer followed by autumn, spring and winter $(\mathrm{p}<0.005$, Table 2$)$.

\section{Larval fish abundance}

Larval $R$. holubi density did not differ between warm temperate and boundary regions ( $\mathrm{W}=45088$, $\mathrm{p}=0.51)$. Larval density differed between seasons $\left(\chi^{2}=21.03, \mathrm{df}=3, \mathrm{p}<0.005\right)$, with higher densities in spring and summer $(\mathrm{p}<0.005)$. Larval density also varied between different salinity zones $\left(\chi^{2}=64.06, \mathrm{df}=5\right.$, $\mathrm{p}<0.005)$, with higher larval densities at mesohaline sites (median $=0$, range $0-91$ ind $/ 100 \mathrm{~m}^{3}$ ), followed by polyhaline (median $=0$, range $0-153 \mathrm{ind} / 100 \mathrm{~m}^{3}$ ), oligo- haline (median=0, range $0-102 \mathrm{ind} / 100 \mathrm{~m}^{3}$ ), euhaline (median $=0$, range $0-71 \mathrm{ind} / 100 \mathrm{~m}^{3}$ ), hypersaline (median $=0$, range $0-14 \mathrm{ind} / 100 \mathrm{~m}^{3}$ ) and freshwater sites $\left(\right.$ median $=0$ ind $\left./ 100 \mathrm{~m}^{3}\right)(\mathrm{p}<0.05)$.

\section{Larval response to environmental variability}

According to the results of AIC model selection statistics (Table 3), for the warm temperate region, Model 1 (i.e. Density Salinity $\times$ Clarity) was found to be the most parsimonious ( $\triangle \mathrm{QAICc}=0$ ) (Table 4 ), with the negative effects of salinity and water clarity interacting with each other to limit the density of $R$. holubi larvae. Model 2 (Density Salinity, $\triangle \mathrm{QAICc}=1.2$ ) ranked as the second most probable exaptation behind the observed variability of $R$. holubi larval density (Table 3 ). The rest of the models listed in Table 3 showed less data support for the hypotheses proposed. However, for the boundary region, Model 1 (i.e. Density Salinity, $\triangle \mathrm{QAICc}=0$ ) and Model 2 
(i.e. Density Clarity, $\triangle \mathrm{QAICc}=0.12$ ) were found to provide almost equally probable hypotheses explaining the observed variation in $R$. holubi larval density (Table 3). Clarity (i.e. Model 2) negatively affected the larval density of $R$. holubi, while salinity (i.e. Model 1) had a positive effect on it (detailed in Table 4). Model 3 (i.e. Density Temperature, $\Delta \mathrm{QAICc}=1.39$ ) and Model 4 (i.e. Density Salinity $\times$ Temperature, $\Delta \mathrm{QAICc}=2.16$ ) showed some data support for the respective hypotheses. The remaining models listed in Table 3 were found to have limited (Model 5, $\Delta \mathrm{AIC}=7.59$ ) or no data support for the hypotheses.

\section{DISCUSSION}

In warm temperate estuaries, $R$. holubi density generally increased in those sections of the estuary where salinity and water clarity were lowest. Additionally, in the estuaries at the boundary of warm temperate and subtropical regions, temperature was a secondary factor affecting densities of $R$. holubi. This supports the hypothesis that postflexion fish larvae such as $R$. holubi prefer less saline and less clear waters with optimal temperatures (Boehlert and Mundy 1988). This is potentially because such conditions are favourable for faster growth rates in some larval fish (Bœuf and Payan 2001, Fiksen et al. 2002, Fielder et al. 2005). Additionally, $R$. holubi larvae may be utilizing less clear sections of estuaries as "visual shelter" or "protective isolation" from predators (Fiksen et al. 2002). Availability of prey items for fish larvae is also known to be higher in mesohaline areas, where nutrients reach a maximum (Snow et al. 2000, Strydom et al. 2003, Chícharo et al. 2006). These highly productive zones at the river-estuary interface have also been characterized as estuarine turbidity maximum (ETM) zones, due to the high incidence of sediment, nutrients, phytoplankton and zooplankton which attract foraging fish larvae and juveniles (Snow et al. 2000, Strydom et al. 2003, Chícharo et al. 2006). Simultaneously, the aforementioned causes may create conditions conducive to higher densities of larvae of $R$. holubi and other fishes, such as Gilchristella aestuaria, which exhibit a close relationship between behaviour and eco-physiology (Strydom 2015). Gilchristella aestuaria dominates the larval fish catch in these estuaries (Strydom 2015), but estuarine species such as $R$. holubi are well adapted to competing for resources in planktonic stages.

Seasonal fluctuations in temperature and salinity influence the density of fish larvae in estuaries of southern Africa and other temperate regions, as adults spawn mainly during the warmer spring and summer months (Faria et al. 2006, Harrison and Whitfield 2006, Strydom 2015). Spring and summer are the primary periods of spawning and recruitment of $R$. holubi into estuaries, coinciding with high rainfall periods in southern-eastern South Africa, excluding the Western Cape (Whitfield 1998, Harrison and Whitfield 2006, Strydom et al. 2014). Despite the seasonal importance of spawning in recruitment, the models indicated that season was not a main factor predicting the density of $R$. holubi in these estuaries. This may indicate that localized variation in environmental factors, such as inter-annual variability in climate and rainfall influencing cueing into estuaries from the nearshore spawning areas, may be more important for $R$. holubi recruitment than time of year (Strydom 2003, Koehn et al. 2011, Kisten et al. 2015). Previous studies have recognized the importance of freshwater inputs in recruitment of early-stage fishes from spawning grounds into estuaries, by providing chemical cues and favourable conditions (Boehlert and Mundy 1988, Strydom 2003, Kisten et al. 2015). Warmer conditions and nutrient inputs boost productivity in estuaries, thereby facilitating increased food availability, faster growth and development of fish larvae during spring and summer (Hays et al. 2005, Islam et al. 2006, Strydom 2015). Mesohaline or ETM zones at the river-estuary interface are usually highly productive (Jerling and Wooldridge 1991, Snow et al. 2000) and likely to support a high density of fish larvae, as previously observed by Islam et al. (2006) and Strydom (2015), and also evident in the current study. Conversely, low densities of $R$. holubi larvae were observed in euhaline and hypersaline zones.

The highest densities of $R$. holubi larvae were recorded in POEs, reflecting the open connection with the ocean, as compared with sporadic overwashing events and seasonal opening of TOCs (Harris and Cyrus 2000, Cowley et al. 2001, Strydom et al. 2003). Rhabdosargus holubi does recruit into some TOCs, but mostly during overwashing and berm-breaching events after major rainfall events, when salinity is lowered and riverine olfactory cues drain into the ocean (Cowley et al. 2001, Strydom 2003). However, R. holubi was absent from all samples collected in the Great Berg Estuary, despite it being a permanently open and highly productive estuary with a high mean rainfall within its distribution range (Whitfield 1998, Montoya-Maya 2009). Further, cool temperate estuaries exhibited no $R$. holubi larvae at the time of sampling. This lack remains unexplained, as results show that lower salinities and water clarity were also recorded in these systems and estuaries were sampled during La Niña or high rainfall periods, and they show no difference in temperature compared with warm temperate and boundary regions.

This study has outlined the importance of estuary type, biogeography, environmental salinity, temperature and water clarity in determining the occurrence and density of $R$. holubi larvae along the southern African coast. Occurrence and abundance of $R$. holubi larvae are optimal at low salinities and low water clarity, and secondarily at optimal temperatures of 15$25^{\circ} \mathrm{C}$. This leads to the high likelihood of finding $R$. holubi in permanently open estuaries within its optimal temperature range. However, in some cases $R$. holubi larvae are able to tolerate more saline, more transparent and colder waters, resulting in a wide distribution and success as estuarine specialists. IPCC $(2013,2014)$ has forecasted temperature increases of up to $3^{\circ} \mathrm{C}$, along with winter rainfall decreases of $10-20 \%$ and summer rainfall increases of $0-10 \%$ in extreme scenarios for the southern-eastern coast of South Africa over the next century. From the results of this study, it would thus seem that species such as $R$. holubi may tolerate the 
predicted changes given their wide range of occurrence (Gillanders et al. 2011, Koehn et al. 2011). However, changing rainfall and evaporation rates could change mouth state regimes, potentially leading to changes in distributions and densities in this and similar species (Gillanders et al. 2011, Koehn et al. 2011, IPCC 2014). For example, it was found that environmental variability in estuaries may be more important than seasonality. As environmental changes occur, this may cause a disjoint in the timing of spawning and recruitment potential, thereby changing larval duration or distribution along the coast (Gillanders et al. 2011, Koehn et al. 2011). The reliance on freshwater flow with associated low salinities (mesohaline) and low water clarity (ETM zones) for supporting high densities of $R$. holubi larvae further supports the hypothesis that similar estuarinedependent species elsewhere in the world may be at risk as freshwater is further extracted or if rainfall decreases and evaporation increases due to climate change. Examples include Acanthopagrus butcheri from Australia and Moore saxatilis and M. americana from America, which rely on freshwater flow for recruitment into estuarine nurseries (North and Houde 2003, Jenkins et al. 2010, Koehn et al. 2011). Moreover, food sources, i.e. plankton density, may also change with changing climate, thereby potentially impacting on estuarinedependent fish populations in the future (Hays et al. 2005, Islam et al. 2006).

\section{ACKNOWLEDGEMENTS}

This research was funded by the National Research Foundation (NRF) through various grants held by NA Strydom (79733, 74346 and 65766), and bursary support was provided by the South African Research Chairs Initiative (SARChI) of the Department of Science and Technology (DST). Any opinions, findings and conclusions or recommendations expressed in this material are those of the authors and the NRF does not accept any liability in this regard.

\section{REFERENCES}

Beckley L.E. 1984. The ichthyofauna of the Sundays Estuary, South Africa, with particular reference to the juvenile marine component. Estuaries 7: 248-258 https://doi.org/10.2307/1352145

Blaber S.J.M. 1973. The ecology of juvenile Rhabdosargus holubi (Steindachner) (Teleostei: Sparidae). Rhodes University, Grahamstown.

Bodinier C., Sucré E., Lecurieux-Belfond L., et al. 2010. Ontogeny of osmoregulation and salinity tolerance in the gilthead sea bream Sparus aurata. Comp. Biochem. Physiol. A 157 : 220-228. https://doi.org/10.1016/j.cbpa.2010.06.185

Boehlert G.W., Mundy B.C. 1988. Roles of behavioral and physical factors in larval and juvenile fish recruitment to estuarine nursery areas. Symp. Am. Fish. Soc. 3: 51-67.

Bœuf G., Payan P. 2001. How should salinity influence fish growth? Comp. Biochem. Physiol. C 130: 411-423. https://doi.org/10.1016/s1532-0456(01)00268-x

Burnham K.P., Anderson D.R. 2002. Model selection and multimodel inference: a practical information-theoretic approach. Springer, New York

Chícharo L., Chícharo M.A., Ben-Hamadou, R. 2006. Use of a hydrotechnical infrastructure (Alqueva Dam) to regulate planktonic assemblages in the Guadiana estuary: basis for sustainable water and ecosystem services management. Est. Coast. Shelf
Sci. 70: 3-18

https://doi.org/10.1016/jecss.2006.05.039

Cowley P., Whitfield A., Bell K. 2001. The surf zone ichthyoplankton adjacent to an intermittently open estuary, with evidence of recruitment during marine overwash events. Est. Coast. Shelf Sci. 52: 339-348 https://doi.org/10.1006/ecss.2000.0710

Dawes C.J. 1998. Marine botany. John Wiley \& Sons, New York.

Faria A., Morais P., Chícharo M.A. 2006. Ichthyoplankton dynamics in the Guadiana estuary and adjacent coastal area, SouthEast Portugal. Est. Coast. Shelf Sci. 70: 85-97. https://doi.org/10.1016/j.ecss.2006.05.032

Fielder D.S., Bardsley W.J., Allan G.L., et al. 2005. The effects of salinity and temperature on growth and survival of Australian snapper, Pagrus auratus larvae. Aquaculture 250: 201-214. https://doi.org/10.1016/j.aquaculture.2005.04.045

Fiksen Ø., Aksnes D.L., Flyum M.H., et al. 2002. The influence of turbidity on growth and survival of fish larvae: a numerical analysis. Hydrobiologia 484: 49-59. https://doi.org/10.1023/A: 1021396719733

Gillanders B.M., Elsdon T.S., Halliday I.A., et al. 2011. Potential effects of climate change on Australian estuaries and fish utilising estuaries: a review. Mar. Freshw. Res. 62: 1115-1131. https://doi.org/10.1071/MF11047

Harris S.A., Cyrus D.P. 2000. Comparison of larval fish assemblages in three large estuarine systems, KwaZulu-Natal, South Africa. Mar. Biol. 137: 527-541. https://doi.org/10.1007/s002270000356

Harrison T.D., Whitfield A.K. 2006. Temperature and salinity as primary determinants influencing the biogeography of fishes in South African estuaries. Est. Coast. Shelf Sci. 66: 335-345. https://doi.org/10.1016/j.ecss.2005.09.010

Hays G.C., Richardson A.J., Robinson C. 2005. Climate change and marine plankton. Trends Ecol. Evol. 20: 337-344. https://doi.org/10.1016/j.tree.2005.03.004

IPCC. 2013. Climate Change 2013: The Physical Science Basis. In: Stocker T.F., et al. (eds) Contribution of Working Group I to the Fifth Assessment Report of the Intergovernmental Panel on Climate Change. Cambridge Univ. Press, Cambridge.

IPCC. 2014. Summary for policymakers. In: Climate Change 2014: Impacts, Adaptation, and Vulnerability. Part A: Global and Sectoral Aspects. Contribution of Working Group II to the Fifth Assessment Report of the Intergovernmental Panel on Climate Change. Cambridge Univ. Press, Cambridge.

Islam M.S., Hibino M., Tanaka M. 2006. Distribution and diets of larval and juvenile fishes: influence of salinity gradient and turbidity maximum in a temperate estuary in upper Ariake Bay, Japan. Est. Coast. Shelf Sci. 68: 62-74. https://doi.org/10.1016/j.ecss.2006.01.010

Jenkins G.P., Conron S.D., Morison A.K. 2010. Highly variable recruitment in an estuarine fish is determined by salinity stratification and freshwater flow: implications of a changing climate. Mar. Ecol. Prog. Ser. 417: 249-261. https://doi.org/10.3354/meps08806

Jerling H., Wooldridge T. 1991. Population dynamics and estimates of production for the calanoid copepod Pseudodiaptomus hessei in a warm temperate estuary. Est. Coast. Shelf Sci. 33: 121-135. https://doi.org/10.1016/0272-7714(91)90002-S

Kisten Y., Pattrick P., Strydom N.A., et al. 2015. Dynamics of recruitment of larval and juvenile Cape stumpnose Rhabdosargus holubi (Teleostei: Sparidae) into the Swartkops and Sundays estuaries, South Africa. Afr. J. Mar. Sci. 37: 1-10. https://doi.org/10.2989/1814232X.2014 998708

Koehn J.D., Hobday A.J., Pratchett M.S., et al. 2011. Climate change and Australian marine and freshwater environments, fishes and fisheries: synthesis and options for adaptation. Mar. Freshw. Res. 62: 1148-1164. https://doi.org/10.1071/MF11139

Lehtiniemi M., Engström-Öst J., Viitasalo M. 2005. Turbidity decreases anti-predator behaviour in pike larvae, Esox lucius. Environ. Biol. Fish. 73: 1-8. https://doi.org/10.1007/s10641-004-5568-4

Montoya-Maya P.H. 2009. Dynamics of larval fish and zooplankton in selected south and west coast estuaries of South Africa. Rhodes University, Grahamstown.

Neira F.J., Potter I.C., Bradley J.A. 1992. Seasonal and spatial changes in the larval fish fauna within a large temperate Australian estuary. Mar. Biol. 112: 1-16. https://doi.org/10.1007/BF00349721

North E.W., Houde E.D. 2003. Linking ETM physics, zooplank- 
ton prey, and fish early-life histories to striped bass Morone saxatilis and white perch $M$. americana recruitment. Mar. Ecol. Prog. Ser. 260: 219-236.

https://doi.org/10.3354/meps260219

R Core Team. 2015. R: A language and environment for statistical computing. R Foundation for Statistical Computing, Vienna, Austria. URL http://www.R-project.org

Snow G., Adams J., Bate G. 2000. Effect of river flow on estuarine microalgal biomass and distribution. Est. Coast. Shelf Sci. 51: 255-266.

https://doi.org/10.1006/ecss.2000.0638

Strydom N.A. 2003. Occurrence of Larval and Early Juvenile Fishes in the Surf Zone Adjacent to two Intermittently Open Estuaries, South Africa. Environ. Biol. Fish. 66: 349-359. https://doi.org/10.1023/A: 1023949607821

Strydom N.A. 2015. Patterns in Larval Fish Diversity, Abundance, and Distribution in Temperate South African Estuaries. Estuaries and Coasts 38: 268-284. https://doi.org/10.1007/s12237-014-9801-x

Strydom N.A., Whitfield A.K. 2000. The effects of a single freshwater release into the Kromme Estuary. 4: Larval fish response. Water SA 26: 319-328.
Strydom N.A., Whitfield A.K., Wooldridge T.H. 2003. The role of estuarine type in characterizing early stage fish assemblages in warm temperate estuaries, South Africa. J. Afr. Zool. 38: 29-43.

Strydom N.A., Booth A.J., McLachlan A. 2014. Occurrence of larval fishes in a rocky shore-associated nursery area in temperate South Africa, with emphasis on temperature-related growth in dominant Sparidae. Afr. J. Mar. Sci. 36: 125-135. https://doi.org/10.2989/1814232X.2014.899269

Vorwerk P.D., Whitfield A.K., Cowley P.D., et al. 2003. The Influence of Selected Environmental Variables on Fish Assemblage Structure in a Range of Southeast African Estuaries. Environ. Biol. Fish. 66: 237-247. https://doi.org/10.1023/A: 1023922521835

Whitfield A.K. 1994. Abundance of larval and 0+ juvenile marine fishes in the lower reaches of three southern African estuaries with differing freshwater inputs. Mar. Ecol. Prog. Ser. 105: 257-267. https://doi.org/10.3354/meps 105257

Whitfield A.K. 1998. Biology and ecology of fishes in South African Estuaries. Ichthyological Monographs of the JLB Smith Institute for Ichthyology, No. 2, Grahamstown. 